FEDERAL RESERVE BANK OF SAN FRANCISCO

WORKING PAPER SERIES

\title{
Reserve Requirements and Optimal Chinese Stabilization Policy
}

\author{
Chun Chang \\ Shanghai Advanced Institute of Finance \\ Shanghai Jiao Tong University \\ Zheng Liu and Mark M. Spiegel \\ Federal Reserve Bank of San Francisco \\ Jingyi Zhang \\ Shanghai Advanced Institute of Finance \\ Shanghai Jiao Tong University
}

March 2018

Working Paper 2016-10

http://www.frbsf.org/economic-research/publications/working-papers/2016/10/

\section{Suggested citation:}

Chang, Chun, Zheng Liu, Mark M. Spiegel, Jingyi Zhang. 2018. "Reserve Requirements and Optimal Chinese Stabilization Policy.” Federal Reserve Bank of San Francisco Working Paper 2016-10. https://doi.org/10.24148/wp2016-10

The views in this paper are solely the responsibility of the authors and should not be interpreted as reflecting the views of the Federal Reserve Bank of San Francisco or the Board of Governors of the Federal Reserve System. This paper was produced under the auspices of the Center for Pacific Basin Studies within the Economic Research Department of the Federal Reserve Bank of San Francisco. 


\title{
RESERVE REQUIREMENTS AND OPTIMAL CHINESE STABILIZATION POLICY
}

\author{
CHUN CHANG, ZHENG LIU, MARK M. SPIEGEL, JINGYI ZHANG
}

\begin{abstract}
We build a two-sector DSGE model to study reserve requirement adjustments, a frequently-used policy tool for macro-stabilization in China. State-owned enterprises (SOEs) are financed by government-guaranteed bank loans, which are subject to reserve requirements, while private firms rely on unregulated off-balance sheet financing. Increasing reserve requirements reallocates resources to more productive private firms, raising aggregate productivity, but also raises the incidence of SOE bankruptcy. Optimal reserve requirement adjustments are complementary to money supply adjustments for improving macroeconomic stability and welfare. However, welfare gains are greater under sector-specific productivity shocks, which call for resource reallocation, than under aggregate productivity shocks.
\end{abstract}

Date: March 19, 2018.

Key words and phrases. Reserve requirements, Chinese monetary policy, off-balance sheet loans, financial accelerator, reallocation and productivity.

JEL classification: E44, E52, G28.

Chang: Shanghai Advanced Institute of Finance, Shanghai Jiao Tong University; Email: cchang@saif.sjtu.edu.cn. Liu: Federal Reserve Bank of San Francisco; Email: Zheng.Liu@sf.frb.org. Spiegel: Federal Reserve Bank of San Francisco; Email: Mark.Spiegel@sf.frb.org. Zhang: Shanghai Advanced Institute of Finance, Shanghai Jiao Tong University; Email: jyZhang.11@saif.sjtu.edu.cn. We are grateful to the Editors Urban Jermann and Vivian Yue and an anonymous referee for insightful comments that helped improve the paper. For helpful discussions, we thank Kaiji Chen, David Cook, Jonathan Ostry, Haibing Shu, Michael Zheng Song, Jian Wang, Shang-Jin Wei, Tao Zha, Feng Zhu, Xiaodong Zhu, and seminar participants at the 2017 Asian Meeting of the Econometric Society, the Federal Reserve Bank of San Francisco, Fudan University, the IMF, the NBER Chinese Economy Meeting, Conference on "Business Cycles, Financial markets, and Monetary Policy" in Beijing, the University of Toronto and Bank of Canada Conference on the Chinese Economy, the Central Bank of Chile Conference on the Chinese Economy, Chinese University of Hong Kong, Hong Kong University of Science and Technology, George Washington University, Zhejiang University, and the HKIMR. We also thank Andrew Tai for research assistance and Anita Todd for editorial assistance. The research is supported by the National Natural Science Foundation of China Project Number 71633003. The views expressed in this paper are those of the authors and do not necessarily reflect the views of the Federal Reserve Bank of San Francisco or the Federal Reserve System. 


\section{INTRODUCTION}

China's central bank, the People's Bank of China (PBOC), frequently uses reserve requirements (RR) as a policy instrument for macroeconomic stabilization. Since 2006, the PBOC has adjusted the required reserve ratio at least 40 times. These changes have also been substantial. For example, during the tightening cycle from 2006 to 2011, the required reserve ratio increased from 8.5 percent to 21.5 percent (see Figure 1).

While many emerging market economies use RR as a policy instrument for stabilizing domestic activity (Federico, Vegh, and Vuletin, 2014), RR adjustments are also used to address external imbalances. For the bulk of countries with open capital accounts, adjusting RR can mitigate potentially disruptive capital flows (Montoro and Moreno, 2011). In the specific case of China, the government has maintained tight controls over both its capital account and the RMB exchange rate. This policy regime allows for substantive and persistent deviations from the interest rate parity. Chang, Liu, and Spiegel (2015) argue that quantitative easing in the advanced economies during the global financial crisis raised the sterilization costs for the PBOC because the interest rates on U.S. Treasuries have fallen substantially relative to Chinas interest rates (such as the SHIBOR). Raising reserve requirements helped to mitigate the PBOCs need to engage in costly sterilization and also reduce the cost of achieving, for example, an exchange rate target or some other macroeconomic policy goals under Chinas tightly controlled capital account regime. ${ }^{1}$

In this paper, we argue that $\mathrm{RR}$ adjustments also have re-allocative consequences under China's existing financial system. The Chinese government provides explicit or implicit guarantees for loans to SOEs (Song, Storesletten, and Zilibotti, 2011). As a result, SOEs enjoy an advantage in raising capital through formal bank borrowing over private firms (POEs). In contrast, POEs, particularly small and medium-sized private firms, raise capital mainly through off-balance sheet lending by commercial banks or by borrowing from informal financial intermediaries or "shadow banks" (Lu, Guo, Kao, and Fung, 2015).

These different borrowing channels face different regulatory conditions. On-balance sheet bank loans to SOEs are subject to RR regulations, while off-balance sheet banking activities are not. As a result, raising RR inhibits SOE financing and encourages the reallocation of capital from the SOE sector to the POE sector. Moreover, since private firms in China are

\footnotetext{
${ }^{1}$ Cun and Li (2017) argue that China's sterilized intervention results in an unintended expansion of bank lending, limiting its effectiveness as a stabilization tool.
} 
on average more productive than SOEs (Hsieh and Klenow, 2009; Hsieh and Song, 2015), holding all else equal, this reallocation may raise aggregate productivity. ${ }^{2}$

We develop a DSGE model to evaluate the implications of RR adjustments for reallocation and macroeconomic stabilization. In the model, intermediate goods are produced by firms in two sectors - an SOE sector and a POE sector-using the same production technology, but with POEs having higher average productivity. The intermediate goods produced by the two sectors are imperfect substitutes. Final goods are produced using a composite of the sectoral intermediate goods and also capital and labor as inputs.

To incorporate financial frictions, we build on the framework of Bernanke, Gertler, and Gilchrist (1999) (BGG). Firms in each sector face aggregate and idiosyncratic productivity shocks. They need to finance working capital with both internal net worth and external debt. As in BGG, there is a threshold level of idiosyncratic productivity, above which firms repay the loans at the contractual interest rate and earn nonnegative profits. Firms with productivity below the threshold level, however, will default, resulting in costly state verification and liquidation.

To illustrate the allocative implications of RR adjustments in China, we extend the BGG framework in several dimensions. First, we assume that bank lending activity is segmented. On-balance sheet loans are provided to SOE firms only, while POE firms can obtain funding only through banks' off-balance sheet activity. This strict separation is a simplification. In reality, both types of firms can obtain funding through both on- and off- balance sheet channels, and SOEs even engage in some lending to POEs. Still, SOEs do receive the substantive majority of on-balance sheet lending, while the POE sector primarily depends on off-balance sheet borrowing from commercial banks and shadow banks (Elliott, Kroeber, and Qiao, 2015). ${ }^{3}$

Second, the government provides guarantees for SOE debt, covering bank losses in the event of an SOE default. This guarantee leads banks to lend at a risk-free interest rate to SOEs, since default losses including deadweight liquidation costs are borne by the governmentand ultimately, by the households, since the government needs to finance the SOE bailout

\footnotetext{
${ }^{2}$ Although SOE productivity is lower on average, firm-level evidence indicates substantial within-sector heterogeneity in productivity. For example, Brandt (2015) shows that both SOEs and POEs have lower productivity in SOE-dominant industries than firms in industries with less SOE presence.

${ }^{3}$ Chang, Chen, Waggoner, and Zha (2015) provide evidence that China's credit policy favors capitalintensive (or heavy) industries at the expense of labor-intensive (or light) industries. While some heavy industry firms are not state-owned, Chang et al. (2015) find that the share of SOEs in capital-intensive industries has increased steadily since the late 1990s reforms. One could more generally interpret our strict financing dichotomy as illustrative of the implications of preferential treatment by the Chinese government across firm types.
} 
costs through lump-sum taxes. Off-balance sheet loans to private firms are not guaranteed, and the financial frictions facing POEs mimic those in the standard BGG environment. In particular, POE loan rates compensate for expected losses under default. In tandem, these assumptions imply that the BGG financial accelerator mechanism is active for the POE sector, but muted for the SOE sector. This leaves POE firms more sensitive to macroeconomic shocks. Furthermore, government guarantees on SOE loans drive a wedge between the relative price of SOE goods and SOE productivity, leading to potentially inefficient fluctuations in SOE relative prices, especially when the economy is buffeted by sector-specific shocks.

Third, RR policy raises the costs of banks' on-balance sheet activity since banks do not earn interest on reserves in our model. Thus, RR policy drives a wedge between the deposit interest rate and the lending rate. ${ }^{4}$

Our model implies that raising $\mathrm{RR}$ discourages on-balance sheet lending activity and reallocates capital from SOEs to POEs. This reallocation mechanism is consistent with empirical evidence from Chinese data, as we show in Section II below. This transmission mechanism differs from conventional monetary policy, which is conducted in China through money supply adjustments (Chen, Ren, and Zha, 2017; Chen, Higgins, Waggoner, and Zha, 2017). While changes in money supply tend to stimulate or contract activities in both the SOE and the POE sectors, an adjustment in RR has different impacts on the two sectors and helps mitigate inefficient relative-price fluctuations. Thus, adjusting RR can be an important complementary policy tool for stabilizing China's macroeconomic fluctuations.

We calibrate our model to illustrate the implications of RR adjustments. We first demonstrate that, in the steady-state equilibrium in our model, adjustments in RR incur a tradeoff. An increase in the steady-state $\mathrm{RR}$ ratio improves aggregate total factor productivity (TFP) by reallocating resources toward the more productive POE sector, but it also raises the incidence of SOE bankruptcies and thus the social costs of SOE bailouts.

We then examine the implications of a simple RR rule and a money growth rule for macroeconomic stability and social welfare under either aggregate or sector-specific productivity shocks. ${ }^{5}$ Under these simple rules, the policy instrument (the RR ratio or the money growth rate) reacts to fluctuations in inflation and the real GDP growth. We then search for optimal rule coefficients that maximize the representative household's welfare. ${ }^{6}$

\footnotetext{
${ }^{4}$ We set the interest rate on reserves to zero for simplicity. The actual current interest rate paid on required reserves in China is $1.62 \%$, far below the $2.74 \%$ one- year government bond rate or the $3.26 \%$ PBOC bills rate, implying that $R R$ do act as a tax on banking activity.

${ }^{5}$ An example of such sector-specific shocks in China is the large-scale SOE restructuring in the late 1990s, which led to significant improvement in the relative productivity of the SOEs (Hsieh and Song, 2015).

${ }^{6}$ We restrict the planner's problem to simple rules because the model proved too complex to solve for the full Ramsey equilibrium.
} 
We evaluate four alternative policy rules. We first consider a benchmark economy in which the monetary authority maintains a constant $\mathrm{RR}$ ratio and adjusts the money growth in response to fluctuations in inflation and output growth, with the money growth rule parameters calibrated based on the empirical evidence documented by Chen et al. (2017). We then examine optimal simple rules, with the parameters in either of these two policy rules chosen optimally to maximize social welfare. Finally, we allow the parameters in both policy rules to be adjusted optimally.

We find that individually optimal RR rule and optimal money growth rule both improve welfare relative to the benchmark policy. Adjusting both instruments optimally yields further welfare gains, suggesting that the two policy instruments are complementary. Furthermore, the magnitudes of the welfare gains obtained from adjusting both reserve requirements and the money growth rate relative to those obtained from optimally adjusting the money growth rate alone depend on the source of the shocks. Gains are greater under situations that call for reallocations of resources across sectors, such as a sector-specific productivity shock, than under aggregate TFP shocks. ${ }^{7}$

Our paper is related to the recent literature on shadow banking in China. For example, Hachem and Song (2015), Chen, Ren, and Zha (2016) Chen et al. (2017), and Wang, Wang, Wang, and Zhou (2016) discuss the underlying factors that drove the dramatic expansion in shadow banking activity in China between 2009 and 2013. Over that period, China's shadow bank lending increased by over 30 percent per year, largely financed by off-balance sheet commercial bank activity in the forms of wealth management products and entrusted loans. Funke, Mihaylovski, and Zhu (2015) study the role of shadow banks for China's monetary policy transmission.

Our work is also related to the earlier literature on sectoral preferences of China's macroeconomic policy. Brandt and Zhu (2000) examine the implications of commitment by the Chinese government for maintaining employment in its less efficient state sector. They find that the cost of fulfilling this commitment has implications for monetary policy and inflation. Song et al. (2011) examine China's transition dynamics in a two-period overlapping generations model with SOEs and POEs. As in our paper, these authors postulate that SOEs have lower productivity, but enjoy superior access to bank credit. Their model's transition dynamics explain some puzzling characteristics of the Chinese economy, such as high growth being accompanied by high saving rates.

\footnotetext{
${ }^{7}$ In an earlier working paper version, we considered an interest rate rule instead of the money growth rule as a benchmark policy regime and obtained qualitatively similar results (see Chang, Liu, Spiegel, and Zhang (2017)).
} 
Our model differs from the earlier literature in three dimensions. First, we investigate an infinite-horizon DSGE model, which accommodates the study of both the steady-state equilibrium and business cycle dynamics. Second, we model financial frictions in the spirit of Bernanke et al. (1999) (BGG). Third, we study the implications of RR policy relative to the conventional monetary policy in an environment with nominal rigidities and financial frictions. In this second-best environment, we find that RR policy is useful for not just steady-state reallocation, but also for business cycle stabilization.

\section{The ReAllocation EFFECts of Reserve Requirement Policy: Some Evidence}

Our model implies that an increase in reserve requirements reallocates capital from SOEs to POEs because it raises the relative cost of on-balance sheet banking activity. In this section, we demonstrate that this reallocation mechanism is consistent with empirical evidence at both the micro level and the macro level.

II.1. Firm-level evidence. We first present some firm-level evidence based on China's equity market data. Our model suggests that an increase in RR directly raises the cost of external financing for SOEs, since they borrow primarily through on-balance sheet channels. In contrast, increases in RR should have a smaller adverse impact on POE activity, since POEs borrow mainly through off-balance sheet activity.

To evaluate the existence of an asymmetric effect of RR changes, we conduct an event study to estimate the announcement effects of changes in RR policy on the equity values of SOEs relative to those of POEs. We use panel data to estimate the empirical specification

$$
\sum_{h=-H}^{H} R_{j, t+h}^{e}=a_{0}+a_{1} \Delta R R_{t-1}+a_{2} S O E_{j t} \times \Delta R R_{t-1}+a_{3} S O E_{j t}+b Z_{j t}+\varepsilon_{j t} .
$$

where the left-hand-side variable $R_{j t}^{e}$ denotes risk-adjusted excess returns for firm $j$ in period $t$, defined as $R_{j t}^{e}=R_{j t}-\hat{\beta}_{j} R_{m t}$, where $R_{j t}$ denotes the firm's stock return, $R_{m t}$ the market return, and $\hat{\beta}_{j}$ the firm's "market beta" (i.e.. the estimated slope coefficient in the regression of the firm's return on a constant and the market return). The dependent variable in our empirical specification is the cumulative risk-adjusted excess returns within the window of time from $H$ days before to $H$ days after a given date $t$. The regressors include $\Delta R R_{t-1}$, which denotes changes in RR; $S O E_{j t}$, which is a 0-1 dummy variable indicating whether the firm is an $\mathrm{SOE} ;{ }^{8}$ interactions between changes in $\mathrm{RR}$ and the SOE dummy; $Z_{j t}$, which is a vector of control variables, including firm size, book-to-market value ratio, industry fixed

\footnotetext{
${ }^{8}$ We identify SOEs as firms that are is directly controlled by the state or has the state as its majority shareholder.
} 
effects, and year fixed effects. The term $\varepsilon_{j t}$ denotes regression errors, assumed to be well behaved.

The parameter of interest is $a_{2}$, the coefficient on the interaction term. It captures the additional sensitivity of SOE stock returns to the announcements of changes in RR policy. In particular, if an increase in $\mathrm{RR}$ reduces the relative SOE stock returns, we should observe that $a_{2}<0$.

We estimate the model in equation (1) using daily data from non-financial firms listed in the Shanghai and Shenzhen stock exchanges for the period from 2005 to 2015. Under China's current regulations, a change in RR policy is not to be signaled or leaked before the actual announcement. Thus, within a relatively short window of time around the announcement date, changes in RR policy are likely to contain some surprise component that can potentially affect stock returns.

Table 1 shows the estimation results for three different window lengths around the RR change announcements: the same day of the announcement $(H=0)$, a three-day window $(H=1)$, and a five-day window $(H=2)$. The estimated value of $a_{2}$ is negative and statistically significant at the $99 \%$ level for all 3 different window lengths. The negative estimates of $a_{2}$ are also economically significant. For example, on the same day of the RR policy change, our point estimate indicates that a one percentage point increase in the required reserve ratio would reduce the daily stock return of an average SOE firm relative to a non-SOE firm by about $0.12 \%$. This corresponds to a monthly reduction in the relative SOE stock returns of about $2.43 \%$, or an annualized reduction of about $33 \% .{ }^{9}$ Our point estimates for the three-day and five-day windows are even larger.

There is reason to believe that this difference in sensitivity is predominantly driven by the latter portion of our sample. In China, the demand for off-balance sheet loans expanded rapidly following the large fiscal stimulus plan that was announced in November 2008 and implemented in 2009-2010. Thus, we expect a stronger reallocation effect of changes in RR in the sample after the fiscal stimulus plan was adopted. ${ }^{10}$

To investigate this possibility, we split our sample into pre- (2005-2008) and post- (20092015) stimulus periods. Our results are shown in Table 2. The estimates of $a_{2}$ are not significantly different from zero in the pre-stimulus period, but become significantly negative in the post-stimulus sample. Moreover, the value of $a_{2}$ estimated in the post-stimulus

\footnotetext{
${ }^{9}$ This calculation is based on 20 trading days per month. The PBOC typically changes the required reserve ratio by 50 basis points, although on some occasions, the size of the change can be as large as 100 basis points.

${ }^{10}$ Cong and Ponticelli (2017) find evidence that China's large-scale fiscal stimulus exacerbated the discrepancies in access to credit between SOEs and POEs, since new credit under the stimulus was primarily allocated toward SOEs.
} 
sample is about twice as large (in absolute terms) as our full-sample estimate shown in Table $1 .{ }^{11}$ Our results therefore indicate that SOE equity values were particularly sensitive to announcements of RR policy changes during the post-stimulus period, when shadow banking activity was expanding rapidly.

II.2. Some VAR evidence. We next present macro evidence that supports the reallocation mechanism of RR adjustments featured in our DSGE model. In particular, this mechanism implies that an increase in $\mathrm{RR}$ should raise the borrowing costs for SOEs, reduce the amount of loans made to SOEs, and lower SOE investment.

Although changes in RR directly affect bank lending rates, the extent to which such changes can affect SOE borrowing and investment remains unclear. With soft budget constraints and monopoly power, SOE activity may be insensitive to changes in market interest rates. We examine the quantitative macro impact of changes in RR on SOE activity using a Bayesian vector-autogression (BVAR) framework.

The BVAR specification that we consider includes 4 variables: new loans to the heavy industry sector (which is a good proxy for SOE loans in light of the evidence in Chang et al. (2015)), the share of SOE investment in total business investment, the one-year benchmark bank lending rate, and the required reserve ratio (RRR). All data are taken from Chang et al. (2015), with a sample range from 2003:Q1 to 2015:Q4. In the baseline BVAR model, we order RRR the last, reflecting our Cholesky identification assumption that RR policy responds to shocks to heavy industry loans, SOE investment shares, and the lending rate in the impact period, but those macro variables do not respond to shocks to RRR on impact. ${ }^{12}$ The BVAR model is estimated with four quarterly lags and with the Sims-Zha priors.

Figure 2 shows the impulse responses to a one standard deviation positive shock to RR, estimated from the BVAR model in our sample. The shock raises RR, pushes up the lending rate, reduces new loans to the heavy industry sector (or SOEs), and reduces the SOE investment share. These macro responses are all statistically significant at the $68 \%$ confidence level.

Our macro evidence based on the estimated BVAR model, along with the firm-level evidence based on the equity market data, lend empirical support to our model's main mechanism. In particular, consistent with our model's predictions, an increase in reserve requirements raises the cost of on-balance sheet loans, which disproportionately weighs on SOE borrowings and reduces the SOE investment share.

\footnotetext{
${ }^{11}$ To conserve space, we only display estimation results for the one- and three-day windows. Results for the five-day window are similar.

${ }^{12}$ We obtained similar qualitative results if RR is ordered the first.
} 
III. THE MODEL

The economy is populated by a continuum of infinitely lived households. The representative household consumes a basket of differentiated goods purchased from retailers. Retailers produce differentiated goods using a homogeneous wholesale good as the only input. The wholesale good is itself a composite of intermediate goods produced by two types of firms: SOEs and POEs. With the exception of SOEs having lower average productivity, the two types of firms have identical ex-ante production technologies.

Firms face working capital constraints. Each firm finances wages and rental payments using both internal net worth and external debt. Following Bernanke et al. (1999), we assume that external financing is subject to a costly state verification problem. In particular, only firms can costlessly observe their own idiosyncratic productivity shocks. Firms with sufficiently low productivity relative to their nominal debt obligations will default and be liquidated. Lenders suffer a liquidation cost when taking over the project to seize available revenue.

We generalize the BGG framework to a two-sector environment with SOEs and POEs that have access to different sources of external financing. We assume that SOEs only borrow through formal on-balance-sheet loans. As is effectively the case in China, we also assume that these loans are backed by government guarantees. In contrast, POEs only borrow through off-balance-sheet loans, which are neither regulated nor backed by the government. While banks face no default risk on the guaranteed loans to SOEs, they face expected default costs for off-balance sheet loans extended to POEs, as in the BGG framework. ${ }^{13}$

We assume that intermediate goods produced by SOEs and by POEs are imperfect substitutes, to ensure positive demand for the lower productivity SOE product. As we show below, financial frictions stemming from government guarantees on SOE loans drive a wedge between the relative price and relative productivity of the SOE sector, causing inefficiencies in resource allocation in both the steady state and over the business cycle. ${ }^{14}$

III.1. Households. There is a continuum of infinitely lived and identical households with unit mass. The representative household has preferences represented by the expected utility

\footnotetext{
${ }^{13}$ Our framework is a simplification that allow for solution of the model. Off-balance sheet lending in China is more diverse and complex, including private loans and corporate bonds. Moreover, large and profitable Chinese private firms typically also have no difficulties accessing bank loans, but rely more on equity and bond markets for capital. In the end, consistent with our assumptions, the bulk of on-balance sheet commercial bank lending goes to SOEs.

${ }^{14}$ In what follows, we focus on describing the main features of the model and we relegate detailed derivations of the equilibrium conditions in an appendix available at the web site http://www.frbsf.org/ economic-research/files/wp2016-10_appendix.pdf
} 
function

$$
U=\mathrm{E} \sum_{t=0}^{\infty} \beta^{t}\left[\ln \left(C_{t}\right)-\Psi \frac{H_{t}^{1+\eta}}{1+\eta}+\Psi_{m} \ln \left(\frac{M_{t}}{P_{t}}\right)\right],
$$

where $\mathrm{E}$ is an expectations operator, $C_{t}$ denotes consumption, $H_{t}$ denotes labor hours, and $M_{t}$ denotes cash holdings. The parameter $\beta \in(0,1)$ is a subjective discount factor, $\eta>0$ is the inverse Frisch elasticity of labor supply, and $\Psi>0$ and $\Psi_{m}>0$ are the relative weights on the disutility of working and the utility of holdings of real cash balances.

The household faces the sequence of budget constraints

$$
C_{t}+I_{t}+\frac{M_{t}}{P_{t}}+\frac{D_{t}}{P_{t}}=w_{t} H_{t}+r_{t}^{k} K_{t-1}+\frac{M_{t-1}}{P_{t}}+R_{t-1} \frac{D_{t-1}}{P_{t}}+T_{t}
$$

where $I_{t}$ denotes capital investment, $D_{t}$ denotes deposits in banks, $w_{t}$ denotes the real wage rate, $r_{t}^{k}$ denotes the real rent rate on capital, $K_{t-1}$ denotes the level of the capital stock at the beginning of period $t, R_{t-1}$ is the gross nominal interest rate on household savings determined from information available in period $t-1, P_{t}$ denotes the price level, and $T_{t}$ denotes the lump-sum transfers (or taxes if negative) from the government and earnings received from firms based on the household's ownership share.

The capital stock evolves according to the law of motion

$$
K_{t}=(1-\delta) K_{t-1}+\left[1-\frac{\Omega_{k}}{2}\left(\frac{I_{t}}{I_{t-1}}-g_{I}\right)^{2}\right] I_{t}
$$

where we have assumed that changes in investment incur an adjustment cost, the scale of which is measured by the parameter $\Omega_{k}>0$. The constant $g_{I}$ denotes the steady-state growth rate of investment.

The household chooses $C_{t}, H_{t}, D_{t}, M_{t}, I_{t}$, and $K_{t}$ to maximize (2), subject to the constraints (3) and (4).

III.2. The retail sector and price setting. There is a continuum of retailers, each producing a differentiated retail product indexed by $z \in[0,1]$. The retail goods are produced using a homogeneous wholesale good, with a constant-returns technology. Retailers are price takers in the input market and face monopolistic competition in the product markets. Retail price adjustments are subject to a quadratic cost, as in Rotemberg (1982).

The production function of retail good of type $z$ is given by

$$
Y_{t}(z)=\Gamma_{t}(z)
$$

where $Y_{t}(z)$ denotes the output of the retail good and $\Gamma_{t}(z)$ the intermediate input. 
The final good for consumption and investment (denoted by $Y_{t}^{f}$ ) is a Dixit-Stiglitz composite of all retail products given by

$$
Y_{t}^{f}=\left[\int_{0}^{1} Y_{t}(z)^{\frac{\epsilon-1}{\epsilon}} d z\right]^{\frac{\epsilon}{\epsilon-1}}
$$

where $\epsilon>1$ denotes the elasticity of substitution between retail goods.

The optimizing decisions of the final good producer lead to a downward-sloping demand schedule for each retail product $z$ :

$$
Y_{t}^{d}(z)=\left(\frac{P_{t}(z)}{P_{t}}\right)^{-\epsilon} Y_{t}^{f}
$$

where $P_{t}(z)$ denotes the price of retail product $z$.

The zero-profit condition for the final good producer implies that the price level $P_{t}$ is related to retail prices by

$$
P_{t}=\left[\int_{0}^{1} P_{t}(z)^{(1-\epsilon)} d z\right]^{1 /(1-\epsilon)} .
$$

Each retailer takes as given the demand schedule (7) and the price level $P_{t}$, and sets a price $P_{t}(z)$ to maximize profits. Price adjustments are costly, with the cost function given by

$$
\frac{\Omega_{p}}{2}\left(\frac{P_{t}(z)}{\pi P_{t-1}(z)}-1\right)^{2} C_{t},
$$

where $\Omega_{p}$ measures the size of the adjustment cost and $\pi$ is the steady-state inflation rate. Retailer $z$ chooses $P_{t}(z)$ to maximize its expected discounted profit

$$
\mathrm{E}_{t} \sum_{i=0}^{\infty} \beta^{i} \Lambda_{t+i}\left[\left(\frac{P_{t+i}(z)}{P_{t+i}}-p_{w, t+i}\right) Y_{t+i}^{d}(z)-\frac{\Omega_{p}}{2}\left(\frac{P_{t+i}(z)}{\pi P_{t+i-1}(z)}-1\right)^{2} C_{t+i}\right],
$$

where $p_{w t}$ is the relative price of the wholesale good (expressed in consumption units) and $Y_{t+i}^{d}(z)$ is given by the demand schedule (7).

We focus on a symmetric equilibrium in which $P_{t}(z)=P_{t}$ for all $z$. The optimal pricesetting decision implies the Phillips curve relation

$$
p_{w t}=\frac{\epsilon-1}{\epsilon}+\frac{\Omega_{p}}{\epsilon} \frac{1}{Y_{t}}\left[\left(\frac{\pi_{t}}{\pi}-1\right) \frac{\pi_{t}}{\pi} C_{t}-\beta \mathrm{E}_{t} \frac{\Lambda_{t+1}}{\Lambda_{t}}\left(\frac{\pi_{t+1}}{\pi}-1\right) \frac{\pi_{t+1}}{\pi} C_{t+1}\right] .
$$

In the special case with no nominal rigidities (i.e., with $\Omega_{p}=0$ ), the retail good price would be a constant markup over the marginal cost, so that the relative price of wholesale goods would be the inverse of the steady-state markup. In general, in the presence of nominal rigidities, the Phillips curve in Equation (10) implies that the current-period inflation $\pi_{t}$ increases with both the real marginal cost and the expected next-period inflation rate. 
III.3. The wholesale sector. Wholesale goods are a composite of intermediate goods from both sectors. Denote by $Y_{s t}$ and $Y_{p t}$ the products produced by SOE firms and POE firms, respectively. The quantity of the wholesale good $\Gamma_{t}$ is given by

$$
\Gamma_{t}=\left(\phi Y_{s t}^{\frac{\sigma-1}{\sigma}}+(1-\phi) Y_{p t}^{\frac{\sigma-1}{\sigma}}\right)^{\frac{\sigma}{\sigma-1}}
$$

where $\phi \in(0,1)$ measures the share of SOE goods and $\sigma>0$ is the elasticity of sbustitution between goods produced by the two sectors.

Denote by $p_{s t}$ and $p_{p t}$ the relative price of SOE products and POE products, respectively, expressed in final consumption units. Cost-minimization implies

$$
Y_{s t}=\phi^{\sigma}\left(\frac{p_{s t}}{p_{w t}}\right)^{-\sigma} \Gamma_{t}, \quad Y_{p t}=(1-\phi)^{\sigma}\left(\frac{p_{p t}}{p_{w t}}\right)^{-\sigma} \Gamma_{t} .
$$

Zero-profits in the wholesale sector imply that

$$
p_{w t}=\left(\phi^{\sigma} p_{s t}^{1-\sigma}+(1-\phi)^{\sigma} p_{s t}^{1-\sigma}\right)^{\frac{1}{1-\sigma}} .
$$

III.4. The intermediate goods sectors. We now present the environment in the SOE and POE intermediate goods sectors. We focus on a representative firm in each sector $j \in\{s, p\}$.

A firm in sector $j$ produces a homogeneous intermediate good $Y_{j t}$ using capital $K_{j t}$ and two types of labor inputs - household labor $H_{j t}$ and entrepreneurial labor $H_{j t}^{e}$, with the production function

$$
Y_{j t}=A_{j t} \omega_{j t}\left(K_{j t}\right)^{1-\alpha}\left[\left(H_{j t}^{e}\right)^{1-\theta} H_{j t}^{\theta}\right]^{\alpha},
$$

where $A_{j t}$ denotes a common productivity shock to all firms in sector $j$, and the parameters $\alpha \in(0,1)$ and $\theta \in(0,1)$ are input elasticities in the production function. The term $\omega_{j t}$ is an idiosyncratic productivity shock at the firm level, and it is an i.i.d. process across firms and time, drawn from the distribution $F(\cdot)$ with a nonnegative support. We assume that the idiosyncratic productivity shocks are drawn from a Pareto distribution with the cumulative density function $F(\omega)=1-\left(\frac{\omega_{m}}{\omega}\right)^{k}$ over the range $\left[\omega_{m}, \infty\right)$, where $\omega_{m}>0$ is the scale parameter and $k$ is the shape parameter. Here, we implicitly assume that the idiosyncratic productivities in both sectors are drawn from the same distribution $F(\cdot)$.

Productivity $A_{j t}$ contains a common deterministic trend $g^{t}$ and a sector-specific stationary component $A_{j t}^{m}$ so that $A_{j t}=g^{t} A_{j t}^{m}$. The stationary component $A_{j t}^{m}$ follows the stochastic process

$$
\ln A_{j t}^{m}=\left(1-\rho_{j}\right) \ln \bar{A}_{j}+\rho_{j} \ln A_{j, t-1}^{m}+\epsilon_{j t},
$$

where $\bar{A}_{j}$ is the steady-state level of $A_{j}^{m}, \rho_{j} \in(-1,1)$ is a persistence parameter, and the term $\epsilon_{j t}$ is an i.i.d. innovation drawn from a log-normal distribution $N\left(0, \sigma_{j}\right)$.

Firms face working capital constraints. In particular, they need to pay wage bills and capital rents before production takes place. Firms finance working capital payments through 
both their beginning-of-period net worth $N_{j, t-1}$ and external debt $B_{j t}$. The working capital constraint for a firm in sector $j \in\{s, p\}$ is given by

$$
\frac{N_{j, t-1}+B_{j t}}{P_{t}}=w_{t} H_{j t}+w_{j t}^{e} H_{j t}^{e}+r_{t}^{k} K_{j t}
$$

where $w_{j t}^{e}$ denotes the real wage rate of managerial labor in sector $j$.

Under constant returns to scale, cost-minimizing factor demand implies that a firm's revenue is a linear function of its net worth, as in Bernanke et al. (1999).

III.5. Financial intermediaries and debt contracts. Financial intermediation takes place through a continuum of competitive representative commercial banks. At the beginning of each period $t$, the representative commercial bank receives deposits $D_{t}$ from the household at interest rate $R_{t}$. The bank makes on-balance-sheet loans $B_{s t}$ to SOE firms, and off-balance-sheet loans $B_{p t}$ to POE firms. On-balance sheet loans are subject to reserve requirements, whereas off-balance sheet loans are not.

In each period, a fraction of firms in both sectors with sufficiently low levels of realized idiosyncratic productivity choose to default on their loan repayments. Off-balance sheet loans do carry default risk. This results in a credit spread on off-balance sheet loans, as in BGG. However, SOE loan losses are covered by the government, eliminating bank default risk.

Given the government guarantees, SOEs face a risk-free loan rate of $R_{s t}$. However, reserve requirements drive a wedge between the loan and deposit interest rates so that

$$
\left(R_{s t}-1\right)\left(1-\tau_{t}\right)=\left(R_{t}-1\right)
$$

where $\tau_{t}$ is the required reserve ratio .

Off-balance sheet lending to POEs is not subject to reserve requirements. Bank funding costs on these loans are therefore equal to $R_{p t}=R_{t}$. Banks charge a higher contractual interest rate $Z_{j t}(j=s, p)$ on all loans ex-ante to cover expected monitoring and liquidation costs. Firms with realized productivity below a cut-off level $\bar{\omega}_{j t}$ will choose to default, where $\bar{\omega}_{j t}$ satisfies

$$
\bar{\omega}_{j t} \equiv \frac{Z_{j t} B_{j t}}{\tilde{A}_{j t}\left(N_{j, t-1}+B_{j t}\right)},
$$

where the term $\tilde{A}_{j t}$, which represents the rate of return on the firm's investment financed by external debt and internal funds, is given by

$$
\tilde{A}_{j t}=p_{j t} A_{j t}\left(\frac{1-\alpha}{r_{t}^{k}}\right)^{1-\alpha}\left[\left(\frac{\alpha(1-\theta)}{w_{j t}^{e}}\right)^{1-\theta}\left(\frac{\alpha \theta}{w_{t}}\right)^{\theta}\right]^{\alpha} .
$$

If a firm defaults, the bank pays the liquidation cost and obtains the firm's generated revenue. In the process, a fraction $m_{j}$ of output is lost. Furthermore, the government is 
assumed to cover a fraction $l_{j}$ of the loan losses financed by lump-sum taxes collected from the households, where $l_{s}=1$ and $l_{p}=0$, i.e. the government covers losses on SOE defaults but not on POE defaults.

We now describe the optimal contract. Denote by $f\left(\bar{\omega}_{j t}\right)$ and $g\left(\bar{\omega}_{j t}\right)$ the share of sector- $j$ income that goes to the borrower and the lender, respectively. The optimal contract is a pair $\left(\bar{\omega}_{j t}, B_{j t}\right)$ chosen at the beginning of period $t$ to maximize the borrower's expected period $t$ income

$$
\max \tilde{A}_{j t}\left(N_{j, t-1}+B_{j t}\right) f\left(\bar{\omega}_{j t}\right)
$$

subject to the lender's participation constraint

$$
\tilde{A}_{j t}\left(N_{j, t-1}+B_{j t}\right) g_{j}\left(\bar{\omega}_{j t}\right) \geq R_{j t} B_{j t}
$$

Finally, following Bernanke et al. (1999), we assume that a manager in sector $j \in\{s, p\}$ survives at the end of each period with probability $\xi_{j}$, so that the average lifespan for the firm is $\frac{1}{1-\xi_{j}}$. The $1-\xi_{j}$ fraction of exiting managers is assumed to be replaced by an equal mass of new managers, so that the population size of managers stays constant. New managers have start-up funds equal to their managerial labor income $w_{j t}^{e} H_{j t}^{e}$. For simplicity, we follow the literature and assume that each manager supplies one unit of labor inelastically and the managerial labor is sector specific (so that $H_{j t}^{e}=1$ for $j \in\{s, p\}$ ).

The end-of-period aggregate net worth of all firms in sector $j$ consists of profits earned by surviving firms plus managerial income

$$
N_{j t}=\xi_{j} \tilde{A}_{j t}\left(N_{j, t-1}+B_{j t}\right) f\left(\bar{\omega}_{j t}\right)+P_{t} w_{j t}^{e} H_{j t}^{e}
$$

III.6. Government policy. Following Chen et al. (2017), we assume that China's central bank (the PBOC) conducts monetary policy using the money supply (M2), rather than interest rates, as the primary policy instrument. ${ }^{15}$ We assume that monetary policy follows a money growth rule, under which the growth rate of broad money supply is adjusted to respond to fluctuations in both the inflation rate and the GDP growth rate. Denote by $\mu_{t}=\frac{M_{t}^{s}}{M_{t-1}^{s}}$ the growth rate of money supply $M_{t}^{s}$. The monetary policy rule is given by

$$
\mu_{t}=\bar{\mu}\left(\frac{\pi_{t}}{\bar{\pi}}\right)^{\psi_{m p}}\left(\frac{\gamma_{t}}{\bar{\gamma}}\right)^{\psi_{m y}}
$$

where the term $\gamma_{t} \equiv \frac{G D P_{t}}{G D P_{t-1}}$ denotes the real GDP growth rate, the constant $\bar{\mu}$ denotes the steady-state money growth rate, $\bar{\pi}$ denotes the steady-state inflation rate, $\bar{\gamma}$ denotes

\footnotetext{
${ }^{15}$ Chen et al. (2017) argues that the PBOC does this because China does not have a well-developed interbank market.
} 
the steady-state real GDP growth rate, and the parameters $\psi_{m p}$ and $\psi_{m y}$ are the response coefficients.

The measure of money supply that we consider in this model corresponds to broad money supply in the data, and it includes both household holdings of currency and banks' on-balance sheet deposits (that is, total deposits net of off-balance sheet lending). In particular, we have

$$
M_{t}^{s}=M_{t}+D_{t}-B_{p t}
$$

We consider two reserve requirement policy regimes. In our benchmark model, we assume that the government fixes the required reserve ratio at $\tau_{t}=\bar{\tau}$. We also consider an alternative reserve requirement policy under which the government varies $\tau_{t}$ in response to fluctuations in inflation and output growth (Section IV.2).

Government spending, including both autonomous spending and spending on SOE bailout costs, are financed through lump-sum taxes on households.

III.7. Market clearing and equilibrium. In equilibrium, the markets for final goods, intermediate goods, capital and labor inputs, and loanable funds all clear. The final goods market clearing implies that

$$
\begin{aligned}
Y_{t}^{f}= & C_{t}+I_{t}+G_{t}+\frac{\Omega_{p}}{2}\left(\frac{\pi_{t}}{\pi}-1\right)^{2} C_{t}+\tilde{A}_{s t} \frac{N_{s, t-1}+B_{s t}}{P_{t}} m_{s} \int_{0}^{\bar{\omega}_{s t}} \omega d F(\omega) \\
& +\tilde{A}_{p t} \frac{N_{p, t-1}+B_{p t}}{P_{t}} m_{p} \int_{0}^{\bar{\omega}_{p t}} \omega d F(\omega),
\end{aligned}
$$

where $G_{t}$ denotes government autonomous spending.

Intermediate goods market clearing implies that

$$
\Gamma_{t}=\left(\phi Y_{s t}^{\frac{\sigma-1}{\sigma}}+(1-\phi) Y_{p t}^{\frac{\sigma-1}{\sigma}}\right)^{\frac{\sigma}{\sigma-1}} .
$$

Factor market clearing implies that

$$
K_{t-1}=K_{s t}+K_{p t}, \quad H_{t}=H_{s t}+H_{p t} .
$$

Loanable funds market clearing implies that

$$
B_{s t} /\left(1-\tau_{t}\right)+B_{p t}=D_{t}
$$

For simplicity, we define real GDP as gross final output net of the costs of firm bankruptcies and price adjustments. In particular, real GDP is defined as

$$
G D P_{t}=C_{t}+I_{t}+G_{t}
$$


We define a measure of aggregate TFP (based on aggregate output) as

$$
\tilde{A}_{Y, t}=\frac{Y_{t}^{f}}{\left(K_{s t}+K_{p t}\right)^{1-\alpha} H_{t}^{\alpha \theta}} .
$$

\section{Quantitative Results}

To evaluate the macroeconomic implications of alternative policy rules, we solve the model numerically based on calibrated parameters.

IV.1. Calibration. We calibrate five sets of parameters in the model. The first set are those in the household decision problem. These include $\beta$, the subjective discount factor; $\eta$, the inverse Frisch elasticity of labor supply; $\Psi$, the utility weight on leisure; $\delta$, the capital depreciation rate; and $\Omega_{k}$, the investment adjustment cost parameter. The second set are those in the retailers' decision problem, including $\epsilon$, the elasticity of substitution between differentiated retail products; and $\Omega_{p}$, the price adjustment cost parameter. The third set includes parameters in the decisions for firms and financial intermediaries. These include $g$, the average trend growth rate; $\omega_{m}$ and $k$, the scale and the shape parameters for the idiosyncratic shock distribution; $\alpha$, the capital share in the production function; $\theta$, the share of labor supplied by the household; $\psi$, the share of SOE products in the intermediate good basket; $\sigma$, the elasticity of substitution between SOE products and POE products; $\bar{A}_{s}$ and $\bar{A}_{p}$, the average productivity of the SOE firms and POE firms, respectively; $m_{s}$ and $m_{p}$, the monitoring costs for SOE firms and POE firms, respectively; and $\xi_{s}$ and $\xi_{p}$, the survival rates of managers for SOE firms and POE firms, respectively. The fourth set of parameters are those in government policy, which include $\bar{\pi}$, steady-state inflation (as well as the inflation target); $\bar{\tau}$, the steady-state required reserve ratio; $\psi_{m p}$ and $\psi_{m y}$, the parameters in the money growth rule; and $\frac{G}{G D P}$, the steady-state ratio of government consumption to real GDP. The fifth set are parameters in the technology shock processes, including $\rho_{j}$ and $\sigma_{j}$, the persistence and standard deviation of the productivity shocks to each sector $j \in\{s, p\}$. Table 3 summarizes the calibrated parameter values.

A period in the model corresponds to one quarter. We set the subjective discount factor to $\beta=0.995$. We set $\eta=2$, implying a Frisch labor elasticity of 0.5 , which lies in the range of empirical studies. We calibrate $\Psi=18$ such that the steady state value of labor hour is about one-third of total time endowment (which itself is normalized to 1). For the parameters in the capital accumulation process, we calibrate $\delta=0.035$, implying an annual depreciation rate of $14 \%$, as in the Chinese data. We have less guidance for calibrating the investment adjustment cost parameter $\Omega_{k}$. We use $\Omega_{k}=1$ as a benchmark, which lies in the range of empirical estimates of DSGE models (Christiano, Eichenbaum, and Evans, 2005; Smets and Wouters, 2007; Liu, Wang, and Zha, 2013). 
For the parameters in the retailers' decision problems, we calibrate the elasticity of substitution between differentiated retail goods $\epsilon$ at 10, implying an average gross markup of $11 \%$, which is in the range estimated by Basu and Fernald (1997). We set $\Omega_{p}=22$, implying an average duration of price contracts of about three quarters. ${ }^{16}$

For the technology parameters, we set the steady-state balanced growth rate to $g=1.0125$, implying an average annual growth rate of $5 \%$. We assume that the idiosyncratic productivity shocks are drawn from a Pareto distribution with the cumulative density function $F(\omega)=$ $1-\left(\frac{\omega_{m}}{\omega}\right)^{k}$ over the range $\left[\omega_{m}, \infty\right)$. We calibrate the scale parameter $\omega_{m}$ and the shape parameter $k$ to match empirical estimates of cross-firm dispersions of TFP in China's data. In particular, Hsieh and Klenow (2009) estimated that the standard deviation of the logarithm of TFP across firms is about 0.63 in 2005. Since $\omega$ is drawn from a Pareto distribution, the logarithm of $\omega$ (scaled by $\omega_{m}$ ) follows an exponential distribution with a standard deviation of $1 / k$. To match the empirical dispersion of TFP estimated by Hsieh and Klenow (2009), we set $k=1 / 0.63$. To keep the mean of $\omega$ at one then requires $\omega_{m}=\frac{k-1}{k}$. This results in $k=1.587$ and $\omega_{m}=0.37$. For the scale parameters in the sector-specific TFP, we normalize $\bar{A}_{s}=1$ and calibrate $\bar{A}_{p}=1.42$, consistent with the average TFP gap between POEs and SOEs estimated by Hsieh and Klenow (2009).

We calibrate the labor income share to $\alpha=0.5$, consistent with empirical evidence in Chinese data (Brandt, Hsieh, and Zhu, 2008; Zhu, 2012). We then calibrate the share of household labor income in total labor income to $\theta=0.9$, implying that the managerial labor share is 0.1 . We set $\psi=0.45$, so that the steady-state share of SOE output in the industrial sector is 0.3 , as in the data. We set the elasticity of substitution between SOE output and POE output to $\sigma=3$, which lies in the range estimated by Chang et al. (2015). ${ }^{17}$

For the parameters associated with financial frictions, we follow Bernanke et al. (1999) and set the liquidation cost parameters to $m_{s}=m_{p}=0.15$. We set the SOE manager's survival rate to $\xi_{s}=0.97$, implying an average term for the SOE manager of about eight years. We set the POE manager's survival rate to $\xi_{p}=0.69$, implying an average term of

\footnotetext{
${ }^{16} \mathrm{Log}$-linearizing the optimal pricing decision equation (10) around the steady state leads to a linear form of Phillips curve relation with the slope of the Phillips curve given by $\kappa=\frac{\epsilon-1}{\Omega_{p}} \frac{C}{Y}$. Our calibration implies a steady state ratio of consumption to gross output of about 50\%. The values of $\epsilon=10$ and $\Omega_{p}=22$ imply that $\kappa=0.2$. In an economy with Calvo-type price contracts, the slope of the Phillips curve is given by $\left(1-\beta \alpha_{p}\right)\left(1-\alpha_{p}\right) / \alpha_{p}$ where $\alpha_{p}$ is the probability that a firm cannot re-optimize prices. To obtain a slope of 0.2 for the Phillips curve in the Calvo model, $\alpha_{p}$ must be set equal to 0.66 , which corresponds to an average duration of price contracts of about three quarters.

${ }^{17}$ Chang et al. (2015) estimate that the elasticity of substitution between SOE and POE output is about 4.53 if annual output data are used. The estimated elasticity is about 1.92 if monthly sales are used to measure output.
} 
about nine months. These survival rates are chosen to yield the steady state outcome that the annual bankruptcy ratio is 0.25 for SOEs and 0.10 for POEs. These numbers match the annual fraction of industrial firms that earns negative profits reported by China's National Bureau of Statistics's (NBS) Annual Industrial Survey.

For the monetary policy parameters, we set the steady-state inflation target $\bar{\pi}$ to $2 \%$ per year. We calibrate the steady-state required reserve ratio to $\bar{\tau}=0.15$. We set the money growth rule parameters to $\psi_{m p}=-0.65$ and $\psi_{m y}=0.30$, consistent with the policy parameters estimated by Chen et al. (2017) for normal times when actual real GDP growth exceeds the policy target. ${ }^{18}$

For the fiscal policy parameters, we set the government consumption-to-GDP ratio at 0.14\%, which corresponds to the sample average in Chinese data from 2001 to 2015.

Finally, for the technology shock parameters, we follow the standard real business cycle literature and set the persistence parameter to $\rho_{j}=0.95$ and the standard deviation parameter to $\sigma_{j}=0.01$ for $j \in\{s, p\}$. In our quantitative analysis below, we consider two separate cases: one with an aggregate TFP shock, so that the two sectoral shocks are perfectly correlated; and the other with sector-specific TFP shocks, so that the two shocks are independent.

IV.2. Simple monetary policy rules. We consider simple monetary policy rules under which the central bank adjusts the relevant policy instrument $(\mu, \tau$, or both) to respond to deviations of the inflation rate and real GDP growth from target.

In our model, there is a steady-state tradeoff associated with the level of reserve requirements. A higher required reserve ratio leads to higher aggregate productivity because it shifts resources from SOEs to POEs. However, a higher $\tau$ also raises the incidence of costly SOE bankruptcies. Under our calibration, there is an interior optimum for the steady state required reserve ratio (at $\tau^{*}=0.34$ ) that maximizes social welfare. However, small deviations from this optimum yield only modest welfare losses. For example, reducing the steady-state value of $\tau$ from the optimal level of 0.34 to our benchmark level of 0.15 only leads to a small welfare loss of about $0.0004 \%$.

In what follows, we focus on the implications of the money growth rule and reserve requirement rule for the stabilization of business cycle fluctuations. We evaluate the effectiveness of

\footnotetext{
${ }^{18}$ The money growth rule considered by Chen et al. (2017) contains lagged money growth along with inflation and GDP growth on the right hand side. For simplicity, we do not include the lagged money growth rate in the monetary policy rule in our model, but we have adjusted our calibration parameters to accommodate this difference. Specifically, their estimated coefficients for lagged money growth, inflation, and GDP growth gap are $0.391,-0.397$, and 0.183 , respectively. We set the policy coefficients in our model to $\psi_{m p}=-0.397 /(1-0.391)=-0.65$ and $\psi_{m y}=0.183 /(1-0.391)=0.30$.
} 
alternative policy rules for macro stabilization against a benchmark policy regime in which the central bank follows the money growth rule, while keeping the required reserve ratio constant at its steady state level. For convenience of references, we rewrite the money growth rule in $\mathrm{Eq}(23)$ in logarithmic form here

$$
\ln \left(\frac{\mu_{t}}{\mu}\right)=\psi_{m p} \ln \left(\frac{\pi_{t}}{\bar{\pi}}\right)+\psi_{m y} \ln \left(\frac{\gamma_{t}}{\bar{\gamma}}\right) .
$$

In the benchmark model, we calibrate the money growth rule parameters $\psi_{m p}$ and $\psi_{m y}$ based on the empirical estimation by Chen et al. (2017).

We also consider a reserve requirement rule in the form

$$
\ln \left(\frac{\tau_{t}}{\tau}\right)=\psi_{\tau p} \ln \left(\frac{\pi_{t}}{\bar{\pi}}\right)+\psi_{\tau y} \ln \left(\frac{\gamma_{t}}{\bar{\gamma}}\right),
$$

where the parameters $\psi_{\tau p}$ and $\psi_{\tau y}$ measure the responsiveness of the required reserve ratio to changes in inflation and real GDP growth.

We compare the macro implications of three alternative policy regimes relative to the benchmark regime. The first alternative policy is an optimal money growth rule, under which the reaction coefficients $\psi_{m p}$ and $\psi_{m y}$ in Eq. (31) are chosen to maximize the representative household's welfare, while the required reserve ratio is kept at the benchmark value (i.e., $\left.\tau_{t}=0.15\right)$. The second alternative policy is an optimal reserve requirement rule, under which the reaction coefficients $\psi_{\tau p}$ and $\psi_{\tau y}$ in Eq. (32) are chosen to maximize welfare, while the money growth rate follows the benchmark policy rule with calibrated values of $\psi_{m p}$ and $\psi_{m y}$. The third alternative policy that we consider is a jointly optimal rule, under which all four reaction coefficients $\psi_{m p}, \psi_{m y}, \psi_{\tau p}$, and $\psi_{\tau y}$ are optimally set to maximize welfare.

We measure welfare gains under each counterfactual policy relative to the benchmark model as the percentage change in permanent consumption that would leave the representative household indifferent between living in an economy under a given optimal policy rule and in the benchmark economy. Denote by $C_{t}^{b}$ and $H_{t}^{b}$ the allocations of consumption and hours worked under the benchmark policy regime. Denote by $V^{a}$ the value of the household's welfare obtained from the equilibrium allocations under an alternative policy regime. Then, the welfare gain under the alternative policy relative to the benchmark is measured by the constant $\chi$, which is implicitly solved from

$$
E \sum_{j=0}^{\infty} \beta^{j}\left[\ln \left(C_{t+j}^{b}(1+\chi)\right)-\Psi \frac{\left(H_{t+j}^{b}\right)^{1+\eta}}{1+\eta}\right]=V^{a} .
$$

IV.3. Macroeconomic implications of optimal policy rules. To study the implications of alternative policy rules for macroeconomic stability and social welfare, we consider two types of shocks: an aggregate TFP shock and a sector-specific TFP shock. In the case with 
a sector-specific shock, we discuss the results under a POE-specific TFP shock in the text and leave the discussions about SOE-specific TFP shocks in the online appendix.

We first consider the case with an aggregate TFP shock. Panel A of Table 4 shows the macroeconomic volatilities under four different policy regimes. It also shows welfare gains for each alternative policy rule relative to the benchmark regime. Under the benchmark policy (Column (1)), the money growth rate responds negatively to deviations of inflation from target and positively to deviations of real GDP growth from the steady state, with the response coefficients calibrated based on Chen et al. (2017). As Chen et al. (2017) argue, the benchmark policy rule reflects the pro-growth monetary policy followed by the PBOC. This pro-growth monetary policy also appears to be consistent with optimal policy when the central bank is restricted to optimizing over either of the two policy instruments in isolation (Columns 2 and 3 in Panel A).

Under the optimal $\tau$ rule (Column 2), the required reserve ratio increases with inflation and decreases with real GDP growth. Thus, the optimal $\tau$ rule leans against inflation fluctuations but accommodates GDP movements. When inflation falls (e.g., following a positive TFP shock), the central bank eases reserve requirements to stimulate aggregate demand and mitigate the fall in inflation. However, the central bank eases reserve requirements when real GDP growth accelerates. Easing reserve requirements helps to mitigate the inefficient boom in aggregate demand stemming from the financial accelerator mechanism in our model. With government guarantees on SOE loans only, the financial accelerator effect is limited to the POE sector. As a result, the POE sector is more cyclically sensitive than the SOE sector. However, easing reserve requirements reallocates resources from the POE sector to the SOE sector, and thus helps stabilize aggregate output fluctuations. Overall, the optimal reserve requirement rule better stabilizes both real GDP and inflation fluctuations than the benchmark policy (judged from the standard deviations of these variables), and it also leads to modest welfare gains relative to the benchmark policy (about $0.0280 \%$ of consumption equivalent).

Under the optimal money growth rule (Column 3), the money growth coefficients are chosen to maximize social welfare while reserve requirements are held constant. Under aggregate TFP shocks, the optimal money growth rule leans against inflation and accommodates real GDP growth. Policy under the optimal money growth rule is therefore qualitatively similar to the pro-growth PBOC policy documented by Chen et al. (2017). In particular, following a positive TFP shock that lowers inflation and raises output, the central bank raises the money supply under the optimal money growth rule. This stimulates aggregate demand and mitigates the decline in inflation. Overall, the optimal money growth rule is more effective 
in stabilizing real GDP and inflation than the benchmark policy. It also leads to a modest welfare gain (about $0.0275 \%$ of consumption equivalent).

Under the jointly optimal policy rule, the central bank can use both policy instruments. Similar to the individually optimal policy rules, the jointly optimal rules lean against inflation. In particular, when the economy is buffeted by aggregate TFP shocks (Panel A, Column (4)), the central bank raises the money growth rate and lowers reserve requirements to mitigate the declines in inflation driven by TFP shocks. The central bank also eases reserve requirements when real GDP growth accelerates. The reduction in reserve requirements not only stimulates aggregate demand by lowering lending rates, which in isolation mitigates the fall in inflation. However, reserve requirement reductions also reallocate resources from the cyclically sensitive POE sector to the less sensitive SOE sector, which reduces aggregate supply and thus helps stabilize output fluctuations. Since the reserve requirement adjustments enhance the central bank's ability to stabilize output, optimal monetary policy exhibits a more standard central bank response, in which the central bank tightens the money supply when GDP growth accelerates. Overall, the jointly optimal policy improves macroeconomic stability relative to the benchmark policy. It also leads to a modest welfare gain relative to the other policy rules. However, these additional welfare gains from pursuing jointly optimal policy are modest, because the aggregate TFP shock does not move relative prices and thus, does not directly call for reallocation of factors across sectors.

If the economy is hit by sector-specific shocks, however, optimal cyclical adjustments in reserve requirements could play a more important role in stabilizing macroeconomic fluctuations and improving welfare. For example, consider the case of an POE-specific productivity shock (shown in Panel B of Table 4).

As in the case with an aggregate TFP shock, we again observe that the individually optimal $\tau$ rule and money growth rule are both effective for improving macroeconomic stability and welfare relative to the benchmark policy regime. However, moving from the individually optimal money growth or reserve requirement rules to the regime with jointly optimal rules under POE-specific TFP shocks results in larger welfare gains than those experienced under aggregate shocks. ${ }^{19}$ In particular, under the jointly optimal rule, the central bank can adjust reserve requirements to alleviate inefficient fluctuations in the relative prices of sectoral goods caused by sector-specific shocks and also adjust money supply growth to yield desired price stability results.

\footnotetext{
${ }^{19} \mathrm{~A}$ similar set of results are obtained in the case with SOE-specific TFP shocks, as we report in the online appendix.
} 
IV.4. Transmission mechanisms. To help understand the economic mechanism underlying our quantitative results, we examine impulse responses. We focus on two different shocks: an aggregate TFP shock and a POE-specific TFP shock.

IV.4.1. Impulse responses to an aggregate TFP shock. Figure 3 displays the impulse responses following a positive aggregate TFP shock under the benchmark policy as well as each of the three alternative policy regimes.

Under the benchmark policy (the black solid line), a positive aggregate TFP shock raises real GDP and lowers inflation, and the central bank responds by expanding the money supply, while the required reserve ratio is kept constant by assumption. The shock raises outputs in both sectors, with more persistent output responses in the POE sector.

As POE leverage rises, the POE bankruptcy rate also increases. This results in a larger credit spread on POE loans. The increase in credit spread makes it more costly for POE firms to borrow, further raising the POE bankruptcy rate. This financial accelerator mechanism leads to persistent responses of POE output. However, given government guarantees, SOE loans bear no default risks. Thus, SOE credit spreads do not respond to changes in aggregate TFP and the financial accelerator mechanism is muted. The improvement in aggregate TFP therefore lowers the SOE bankruptcy rate. Overall, the shock generates a positive, but relatively short-lived SOE output response.

The aggregate TFP shock leads to different aggregate dynamics under the three counterfactual policy regimes. Consider first the optimal reserve requirement $(\tau)$ rule. As discussed in Section IV.3, the optimal $\tau$ rule leans against inflation and accommodates fluctuations in real GDP growth. Since the aggregate TFP shock reduces inflation and raises output, the central bank responds by easing reserve requirements to stimulate aggregate demand and mitigate the decline in inflation. Figure 3 shows that the optimal $\tau$ rule (the red dashed lines) is very effective in dampening inflation fluctuations. It also generate larger but less persistent output responses through than those under the benchmark policy. The optimal adjustments in $\tau$ also reallocate resources across sectors. By lowering the funding costs for SOE firms, the policy response reduces the probability of SOE bankruptcies. All else equal, this shifts resources from the POE sector to the SOE sector, leading to a larger boom in SOE output than in POE output. However, the aggregate demand effect offsets this reallocation effect. As aggregate demand rises following the reduction in $\tau$, the financial accelerator that operates in the POE sector leads to greater responses in POE output. Under our calibration, the aggregate demand effect dominates the reallocation effect, and the shock thus raises POE output more than SOE output.

Under the optimal money growth $(\mu)$ rule, the decline in inflation and the acceleration in real GDP growth both call for a more aggressive expansion of money supply. As shown in 
Figure 3, the optimal $\mu$ rule (the blue dashed lines) is also effective for stabilizing inflation. As money growth accelerates, the nominal deposit rate falls to clear the money market and reduces the funding costs for SOE firms. This lowers the SOE bankruptcy ratio. The expansion in money supply also stimulates aggregate demand and raises POE output more than SOE output through the financial accelerator mechanism.

Under the jointly optimal policy (the magenta dashed lines), the central bank adjusts both $\tau$ and $\mu$. As discussed in Section IV.3, both instruments are used to stabilize inflation, resulting in muted inflation responses to the aggregate TFP shock. However, unlike the other policy rules, the jointly optimal policy calls for adjusting the money growth rate to lean against GDP fluctuations. Thus, under this policy regime, both money growth and the required reserve ratio decline sharply in response to the positive TFP shock. Since the central bank is able to also use reserve requirements to stabilize inflation, the money growth instrument is "freed up" to stabilize output fluctuations. Quantitatively, the jointly optimal policy leads to slightly smaller and less persistent fluctuations in real GDP compared to the individually optimal rules.

IV.4.2. Impulse responses to a POE-specific TFP shock. Figure 4 shows the impulse responses following a positive, POE-specific TFP shock under the four alternative policy regimes.

Under the benchmark policy, the POE-specific TFP shock raises both real GDP and inflation. The shock also reallocates capital and labor toward the more productive POE sector, so that POE output expands and SOE output contracts. To finance the output expansion, POE leverage increases, leading to a rise in the POE bankruptcy rate. Since POE demand for off-balance sheet loans rises, the competition for funding also raises the interest rate for on-balance sheet loans to SOEs. Thus, the SOE bankruptcy rate also increases.

The increase in inflation following a positive POE-specific TFP shock is somewhat surprising. In a standard one-sector model, a positive TFP shock typically reduces inflation. In our model, however, the change in inflation depends on the relative strength of two competing forces: the standard mechanism through which a productivity improvement reduces inflation and a new mechanism stemming from money market equilibrium.

The money market clearing condition (24) satisfies

$$
M_{t}^{s}=M_{t}+D_{t}-B_{p t}
$$

Under the benchmark policy, money supply growth responds with fixed coefficients to inflation and real GDP. The improvement in POE productivity drives up demand for POE loans (i.e., $B_{p t}$ rises), which reduces the available funds for SOEs $\left(D_{t}-B_{p t}\right)$. For any given money 
supply $\left(M_{t}^{s}\right)$, the decline in SOE loans requires an increase in households' cash holdings $\left(M_{t}\right)$ to clear the money market. This in turn requires a decline in the nominal interest rate on deposits (i.e., a fall in the opportunity cost of holding cash). The decline in the nominal interest rate stimulates aggregate demand and raise inflation. On the other hand, the improvement in POE TFP also raises aggregate productivity, which reduces the relative price of intermediate goods and thus the real marginal cost facing price-setting firms. This cost-reduction effect tends to lower inflation, as in the standard one-sector model. Under our calibrated parameters, the aggregate demand channel dominates, leading to an increase in inflation following a positive POE productivity shock.

Under the optimal $\tau$ rule, the central bank responds to the increase in inflation by raising reserve requirements and to the increase in real GDP growth by lowering reserve requirements. The net outcome is an initial decline in $\tau$ followed by a subsequent increase, as shown in Figure 4. The optimal $\tau$ rule dampens substantially the inflation responses and amplifies modestly the real GDP responses to the shock, and the responses of both real GDP and inflation become less persistent than under the benchmark policy. The short-run reduction in reserve requirements under the optimal $\tau$ rule also shifts capital and labor from the POE sector to the SOE sector. All else equal, this would dampen the increases in output of the POE sector relative to the SOE sector. However, since the financial accelerator is operative in the POE sector (but not in the SOE sector), the expansion in aggregate demand under the optimal $\tau$ rule amplifies the increases in POE's relative output. The decline in $\tau$ also reduces the SOE bankruptcy rate relative to the benchmark.

Under the optimal $\mu$ rule, the central bank leans against inflation and accommodates GDP growth. In particular, $\mu$ decreases with inflation and increases with real GDP growth. Compared to the benchmark policy, the optimal $\mu$ rule leads to smaller increases in inflation following the POE TFP shock, and modestly larger and less persistent increases in real GDP. On net, the money growth rate increases more sharply in the short run than under the benchmark policy, resulting in an expansion in aggregate demand. Since the POE sector is more cyclically sensitive, the increase in aggregate demand further amplifies the relative increase in POE output compared to that in the benchmark economy.

Under the jointly optimal policy rule, the required reserve ratio increases with inflation and decreases with real GDP growth, as shown in Table 4 (Column (4) in Panel B). These policy reactions are qualitatively similar to those under the individually optimal $\tau$ rule. However, unlike the benchmark policy and the individually optimal $\mu$ rule, the jointly optimal policy calls for adjusting money growth to lean against both inflation and real GDP growth. Since the POE productivity shock raises both inflation and GDP growth, the money growth rate declines under the jointly optimal rules, as shown in Figure 4. The reduction in money 
supply growth dampens aggregate demand and mutes the inflation response. Inflation rises modestly in the initial period, and falls below its steady state value before gradually returning to the steady state from below. The persistent decline in inflation calls for a reduction in the reserve requirements, as shown in the figure. Similar to the individually optimal $\tau$ rule, the decline in reserve requirements stimulates aggregate demand while shifting resources from POEs to SOEs. Under our calibration, the aggregate demand effect dominates so that the relative POE output increases more than it does under the benchmark policy.

The impulse responses, together with the macroeconomic stability results, suggest that the two policy instruments - money growth and reserve requirements - are complementary for macroeconomic stabilization, especially under sector-specific shocks that call for adjusting resource allocations.

\section{Conclusion}

We study the benefits from adjusting reserve requirements as a policy instrument in a two-sector DSGE model with Chinese characteristics. Our model generalizes the standard financial accelerator model of Bernanke et al. (1999) to include two key forms of frictions. First, the model features segmented credit markets, in which SOE firms are able to obtain on-balance sheet bank loans, while POE firms rely on off-balance sheet lending for financing. Second, the government provides guarantees for formal bank loans to SOE firms, but not to off-balance sheet activity.

We show that government guarantees of SOE loans are an important source of distortions and that adjustments in reserve requirements can be an effective second-best policy. By adjusting reserve requirements, the central bank can influence the allocation of credit and capital across the two sectors. Such adjustments can not only alleviate steady-state distortions but can also help stabilize business cycle fluctuations.

Under our calibration, adjusting the money supply remains the primary policy instrument for macroeconomic stabilization. However, the welfare gains from the ability to also adjust reserve requirements depends on the type of shock. When the money supply policy is optimized under an aggregate TFP shock, allowing the central bank to also optimally set the required reserve ratio provides only modest welfare gains. When the economy is hit by sector-specific productivity shocks, however, adding the reserve requirement policy tool results in greater macroeconomic stabilization and welfare gains.

Our results are second best by design. A more effective long-term reform would be to address the distortions in our framework explicitly, in particular to reduce or eliminate the 
distortion from the government guarantees on SOE loans. More broadly, our analysis suggests potential welfare gains from coordination between banking regulations and monetary policy in China. 


\section{REFERENCES}

Basu, S. and J. G. Fernald (1997). Returns to scale in u.s. production: Estimates and implications. Journal of Political Economy 105(2), 249-283.

Bernanke, B., M. Gertler, and S. Gilchrist (1999). The financial accelerator in a quantitative business cycle framework. In J. B. Taylor and M. Woodford (Eds.), Handbook of Macroeconomics, pp. 1341-1393. Amsterdam, New York, and Oxford: Elsevier Science.

Brandt, L. (2015). Policy perspectives from the bottom up: What do firm-level data tell us China needs to do? In R. Glick and M. M. Spiegel (Eds.), Policy Challenges in a Diverging Global Economy: Proceedings from the 2015 Asia Economic Policy Conference, San Francisco, CA. Federal Reserve Bank of San Francisco: Federal Reserve Bank of San Francisco.

Brandt, L., C.-T. Hsieh, and X. Zhu (2008). Growth and structural transformation in China. In L. Brandt and T. G. Rawski (Eds.), China's Great Economic Transformation, pp. 683728. Cambridge University Press.

Brandt, L. and X. Zhu (2000). Redistribution in a decentralized economy. Journal of Political Economy 108(2), 422-439.

Chang, C., K. Chen, D. F. Waggoner, and T. Zha (2015). Trends and cycles in China's macroeconomy. In M. Eichenbaum and J. Parker (Eds.), NBER Macroeconomics Annual 2015, Volume 30, pp. 1-84. University of Chicago Press.

Chang, C., Z. Liu, and M. M. Spiegel (2015). Capital controls and optimal Chinese monetary policy. Journal of Monetary Economics 74, 1-15.

Chang, C., Z. Liu, M. M. Spiegel, and J. Zhang (2017). Reserve requirements and optimal Chinese stabilization policy. Federal Reserve Bank of San Francisco Working Paper 201610.

Chen, K., P. Higgins, D. F. Waggoner, and T. Zha (2017, September). Impacts of monetary stimulus on credit allocation and macroeconomy: Evidence from China. NBER Working Paper No. 22650.

Chen, K., J. Ren, and T. Zha (2016, March). What we learn from China's rising shadow banking: Exploring the nexus of monetary tightening and banks' role in entrusted lending. Unpublished Manuscript, Emory University and the Federal Reserve Bank of Atlanta.

Chen, K., J. Ren, and T. Zha (2017, May). The nexus of monetary policy and shadow banking in China. NBER Working Paper No. 23377.

Christiano, L. J., M. Eichenbaum, and C. L. Evans (2005). Nominal rigidities and the dynamic effects of a shock to monetary policy. Journal of Political Economy 113(1), $1-45$. 
Cong, L. W. and J. Ponticelli (2017, February). Credit allocation under economic stimulus: Evidence from China. Unpublished Manuscript, University of Chicago Booth School of Business.

Cun, W. and J. Li (2017, July). Sterilized intervention, bank credit, and Chinese monetary policy. Unpublished Manuscript, USC Dornsife and Cantral University of Finance and Economics.

Elliott, D., A. Kroeber, and Y. Qiao (2015). Shadow banking in China: A primer. The Brooking Institution.

Federico, P., C. A. Vegh, and G. Vuletin (2014, October). Reserve requirement policy over the business cycle. NBER Working Paper No. 20612.

Funke, M., P. Mihaylovski, and H. Zhu (2015, September). Monetary policy transmission in China: A DSGE model with parallel shadow banking and interest rate control. Bank of Finland BOFIT Discussion Papers.

Hachem, K. and Z. M. Song (2015). The rise of Chinas shadow banking system. Unpublished manuscript, Chicago Booth.

Hsieh, C.-T. and P. J. Klenow (2009, November). Misallocation and manufacturing TFP in China and India. The Quarterly Journal of Economics 124(4), 1403-1448.

Hsieh, C.-T. and Z. M. Song (2015, March). Grasp the large, let go of the small: The transformation of the state sector in China. In J. C. Eberly and J. H. Stock (Eds.), Brookings Papers on Economic Activity, Volume Spring, pp. 295-366. The Brookings Institution.

Liu, Z., P. Wang, and T. Zha (2013, May). Land-price dynamics and macroeconomic fluctuations. Econometrica 81(3), 1147-1184.

Lu, Y., H. Guo, E. H. Kao, and H.-G. Fung (2015). Shadow banking and firm financing in China. International Review of Economics and Finance 36, 40-53.

Montoro, C. and R. Moreno (2011, March). The use of reserve requirements as a policy instrument in Latin America. BIS Quarterly Review, 53-65.

Rotemberg, J. J. (1982). Sticky prices in the United States. Journal of Political Economy 90(6), 1187-1211.

Smets, F. and R. Wouters (2007). Shocks and frictions in US business cycles: A Bayesian DSGE approach. American Economic Review 97(3), 586-606.

Song, Z., K. Storesletten, and F. Zilibotti (2011). Growing like China. American Economic Review 101(1), 196-233.

Wang, H., H. Wang, L. Wang, and H. Zhou (2016, May). Shadow banking: China's dualtrack interest rate liberalization. Unfinished Manuscript, Tsinghua University.

Zhu, X. (2012). Understanding China's growth: Past, present, and future. Journal of Economic Perspectives 26(4), 103-124. 
TABLE 1. Announcement Effects of RR policy on stock returns

\begin{tabular}{cccc}
\hline \hline Event window & 1-day $(\mathrm{H}=0)$ & 3 -day $(\mathrm{H}=1)$ & 5 -day $(\mathrm{H}=2)$ \\
\hline$\Delta R R_{t-1}$ & 0.00206 & 0.00479 & 0.01057 \\
& $(7.20)$ & $(9.21)$ & $(15.74)$ \\
$\mathbf{S O E}_{\mathbf{j t}} \times \boldsymbol{\Delta} \mathbf{R R}_{\mathbf{t}-\mathbf{1}}$ & -0.0012 & -0.00225 & -0.00442 \\
& $(-3.21)$ & $(-3.32)$ & $(-5.05)$ \\
$S O E_{j t}$ & -0.00007 & -0.00026 & -0.00041 \\
& $(-2.60)$ & $(-5.29)$ & $(-6.47)$ \\
Firm size & -0.00034 & -0.00099 & -0.00155 \\
& $(-27)$ & $(-43)$ & $(-53)$ \\
Book-to-market ratio & 0.00009 & 0.00024 & 0.00047 \\
Industry fixed effects & $(2.22)$ & $(3.29)$ & $(4.96)$ \\
Year fixed effects & $\mathrm{Y}$ & $\mathrm{Y}$ & $\mathrm{Y}$ \\
Sample size & $4,119,971$ & $4,079,847$ & $4,0003,53$ \\
$R^{2}$ & 0.00071 & 0.00182 & 0.00288 \\
\hline \hline
\end{tabular}

Note: For each coefficient, the upper row displays the estimated valued and the numbers shown in parantheses are the t-statistics. The critical values of t-statistics are 1.64. 1.96, and 2.58 for the $10 \%, 5 \%$, and $1 \%$ significance levels, respectively. 
TABLE 2. Announcement Effects of RR policy on stock returns: Before and after fiscal stimulus

\begin{tabular}{ccccc}
\hline \hline & \multicolumn{2}{c}{ Pre-stimulus $(2005-2008)$} & \multicolumn{2}{c}{ Post-stimulus $(2009-2015)$} \\
\hline Event window & 1-day $(\mathrm{H}=0)$ & 3-day $(\mathrm{H}=1)$ & 1-day $(\mathrm{H}=0)$ & 3-day $(\mathrm{H}=1)$ \\
\hline$\Delta R R_{t-1}$ & 0.0010 & 0.0003 & 0.0029 & 0.0081 \\
$\mathbf{S O E}_{\mathbf{j t}} \times \boldsymbol{\Delta} \mathbf{R R}_{\mathbf{t}-\mathbf{1}}$ & $(2.00)$ & $(0.31)$ & $(8.08)$ & $(12.57)$ \\
& 0.0001 & 0.0012 & -0.0024 & -0.0046 \\
$S O E_{j t}$ & $(0.11)$ & $(1.03)$ & $(-4.78)$ & -5.03 \\
& 0.00002 & 0.0005 & -0.0002 & -0.0005 \\
Firm size & $(2.90)$ & $(4.09)$ & $(-4.85)$ & $(-8.86)$ \\
& -0.0003 & -0.0008 & -0.0004 & -0.0011 \\
Book-to-market ratio & $(-9)$ & $(-14)$ & $(-26)$ & $(-41)$ \\
& 0.0000 & 0.0001 & 0.0001 & 0.0004 \\
Industry fixed effects & $(-0.25)$ & $(-0.56)$ & $(2.91)$ & $(4.50)$ \\
Year fixed effects & $\mathrm{Y}$ & $\mathrm{Y}$ & $\mathrm{Y}$ & $\mathrm{Y}$ \\
Sample size & $\mathrm{Y}$ & $\mathrm{Y}$ & $\mathrm{Y}$ & $\mathrm{Y}$ \\
$R^{2}$ & $1,018,628$ & $1,003,518$ & $3,101,343$ & $3,076,329$ \\
& 0.0005 & 0.0011 & 0.0008 & 0.0022 \\
\hline \hline
\end{tabular}

Note: For each coefficient, the upper row displays the estimated valued and the numbers shown in parantheses are the t-statistics. The critical values of t-statistics are 1.64. 1.96, and 2.58 for the $10 \%, 5 \%$, and $1 \%$ significance levels, respectively. 
TABle 3. Calibrated values.

\begin{tabular}{|c|c|c|}
\hline Variable & Description & Value \\
\hline \multicolumn{3}{|c|}{ A. Households } \\
\hline$\beta$ & Subjective discount factor & 0.995 \\
\hline$\eta$ & Inverse Frisch elasticity of labor supply & 2 \\
\hline$\Psi$ & Weight of disutility of working & 18 \\
\hline$\delta$ & Capital depreciation rate & 0.035 \\
\hline$\Omega_{k}$ & Capital adjustment cost & 1 \\
\hline \multicolumn{3}{|c|}{ B. Retailers } \\
\hline$\epsilon$ & Elasticity of substitution between retail products & 10 \\
\hline$\Omega_{p}$ & Price adjustment cost parameter & 22 \\
\hline \multicolumn{3}{|c|}{ C. Firms and financial intermediaries } \\
\hline$g$ & Steady state growth rate & 1.0125 \\
\hline$k$ & Shape parameter in Pareto distribution of idiosyncratic shocks & 1.587 \\
\hline$\omega_{m}$ & Scale parameter in Pareto distribution of idiosyncratic shocks & 0.37 \\
\hline$A_{s}$ & SOE TFP scale (normalized) & 1 \\
\hline$A_{p}$ & POE TFP scale & 1.42 \\
\hline$\alpha$ & Capital income share & 0.5 \\
\hline$\theta$ & Share of household labor & 0.94 \\
\hline$\psi$ & Share parameter for SOE output in intermediate good & 0.45 \\
\hline$\sigma$ & Elasticity of substitution between SOE and POE products & 3 \\
\hline$m_{s}$ & SOE monitoring cost & 0.15 \\
\hline$m_{p}$ & POE monitoring cost & 0.15 \\
\hline$\xi_{s}$ & SOE manager's survival rate & 0.97 \\
\hline$\xi_{p}$ & POE manager's survival rate & 0.69 \\
\hline \multicolumn{3}{|c|}{ D. Government policy } \\
\hline$\pi$ & Steady state inflation rate & 1.005 \\
\hline$\tau$ & Required reserve ratio & 0.15 \\
\hline$\psi_{m p}$ & Money growth rule coefficient for inflation & -0.65 \\
\hline$\psi_{m y}$ & Money growth rule coefficient for output & 0.30 \\
\hline$\frac{G}{G D P}$ & Share of government spending in GDP & 0.14 \\
\hline$l_{s}$ & Fraction of SOE debt guaranteed by the government & 1 \\
\hline$l_{p}$ & Fraction of SOE debt guaranteed by the government & 0 \\
\hline \multicolumn{3}{|c|}{ E. Shock process } \\
\hline$\rho_{a}$ & Persistence of TFP shock & 0.95 \\
\hline$\sigma_{a}$ & Standard deviation of TFP shock & 0.01 \\
\hline
\end{tabular}


TABLE 4. Volatilities and welfare under alternative policy rules

\begin{tabular}{|c|c|c|c|c|}
\hline Variables & (1) Benchmark & (2) Optimal $\tau$ rule & (3) Optimal money rule & (4) Jointly optimal rule \\
\hline \multicolumn{5}{|c|}{ Panel A: Aggregate TFP shock } \\
\hline \multicolumn{5}{|c|}{ Policy rule coefficients } \\
\hline$\psi_{m p}$ & -0.65 & -0.65 & -47.54 & -63.40 \\
\hline$\psi_{m y}$ & 0.30 & 0.30 & 2.68 & -12.50 \\
\hline$\psi_{\tau p}$ & 0.00 & 32.06 & 0.00 & 357.89 \\
\hline$\psi_{\tau y}$ & 0.00 & -2.42 & 0.00 & -19.26 \\
\hline \multicolumn{5}{|c|}{ Volatility and welfare } \\
\hline$G D P$ & $5.284 \%$ & $5.231 \%$ & $5.220 \%$ & $5.205 \%$ \\
\hline$\pi$ & $0.517 \%$ & $0.076 \%$ & $0.020 \%$ & $0.064 \%$ \\
\hline$C$ & $4.422 \%$ & $4.373 \%$ & $4.356 \%$ & $4.363 \%$ \\
\hline$Y_{s}$ & $5.352 \%$ & $5.369 \%$ & $5.305 \%$ & $5.515 \%$ \\
\hline$Y_{p}$ & $5.434 \%$ & $5.523 \%$ & $5.525 \%$ & $5.430 \%$ \\
\hline Welfare gains & - & $0.0280 \%$ & $0.0275 \%$ & $0.0281 \%$ \\
\hline \multicolumn{5}{|c|}{ Panel B: POE-specific TFP shock } \\
\hline \multicolumn{5}{|c|}{ Policy rule coefficients } \\
\hline$\psi_{m p}$ & -0.65 & -0.65 & -45.42 & -2.44 \\
\hline$\psi_{m y}$ & 0.30 & 0.30 & 4.42 & -1.42 \\
\hline$\psi_{\tau p}$ & 0.00 & 35.44 & 0.00 & 28.18 \\
\hline$\psi_{\tau y}$ & 0.00 & -4.40 & 0.00 & -5.61 \\
\hline \multicolumn{5}{|c|}{ Volatility and welfare } \\
\hline$G D P$ & $3.828 \%$ & $3.817 \%$ & $3.809 \%$ & $3.812 \%$ \\
\hline$\pi$ & $0.180 \%$ & $0.067 \%$ & $0.046 \%$ & $0.093 \%$ \\
\hline$C$ & $3.284 \%$ & $3.275 \%$ & $3.273 \%$ & $3.288 \%$ \\
\hline$Y_{s}$ & $2.848 \%$ & $2.830 \%$ & $2.817 \%$ & $2.727 \%$ \\
\hline$Y_{p}$ & $6.549 \%$ & $6.539 \%$ & $6.529 \%$ & $6.518 \%$ \\
\hline Welfare gains & - & $0.0031 \%$ & $0.0032 \%$ & $0.0040 \%$ \\
\hline
\end{tabular}


China required reserve ratio

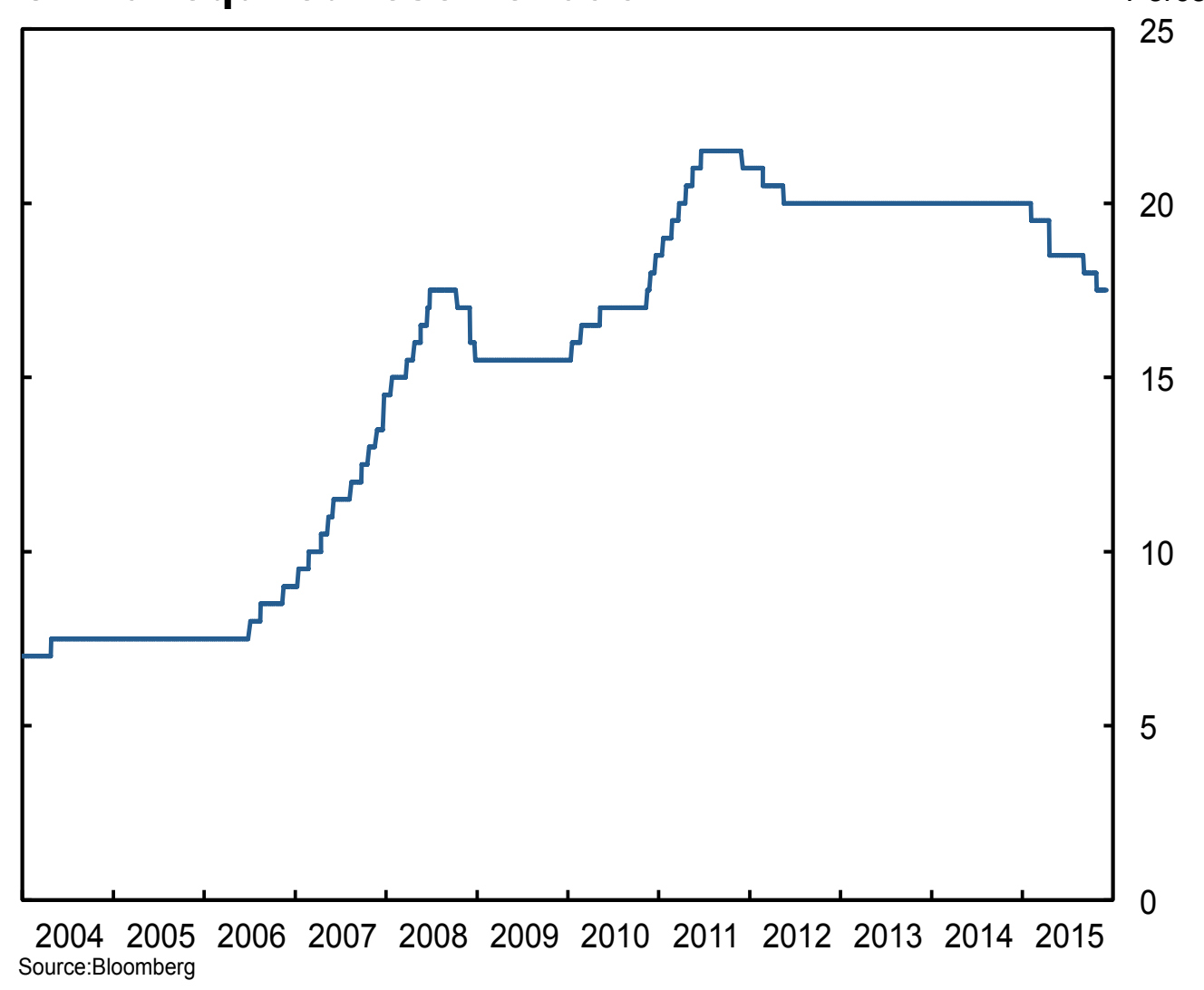

FiguRE 1. China's required reserve ratio (daily frequencies). 

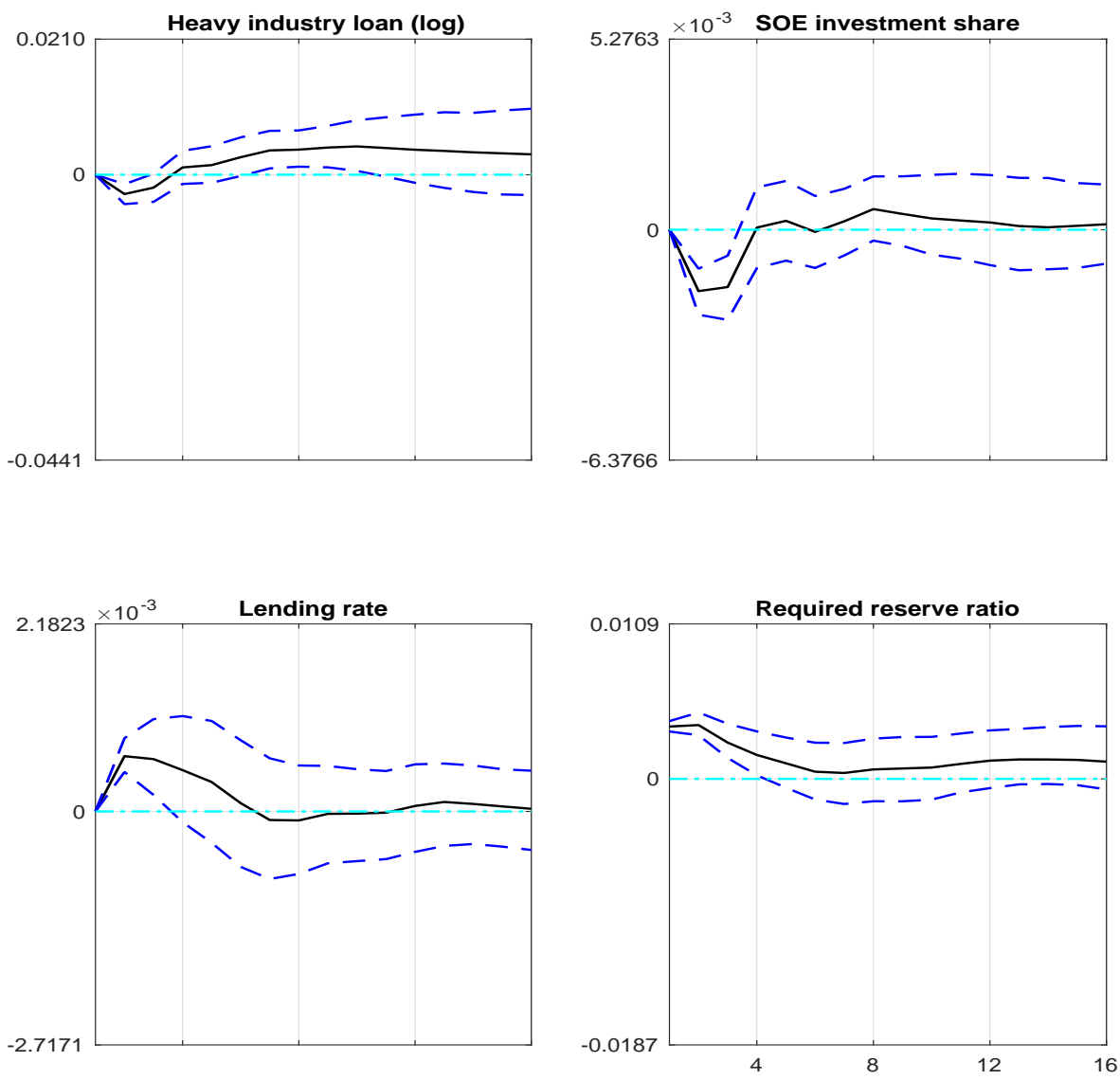

FiguRE 2. Impulse responses of heavy industry loans, SOE investment share, one-year benchmark lending interest rate, the required reserve ratio (RRR) following a shock to RRR in an estimated BVAR model. 
Impulse responses to TFP shock
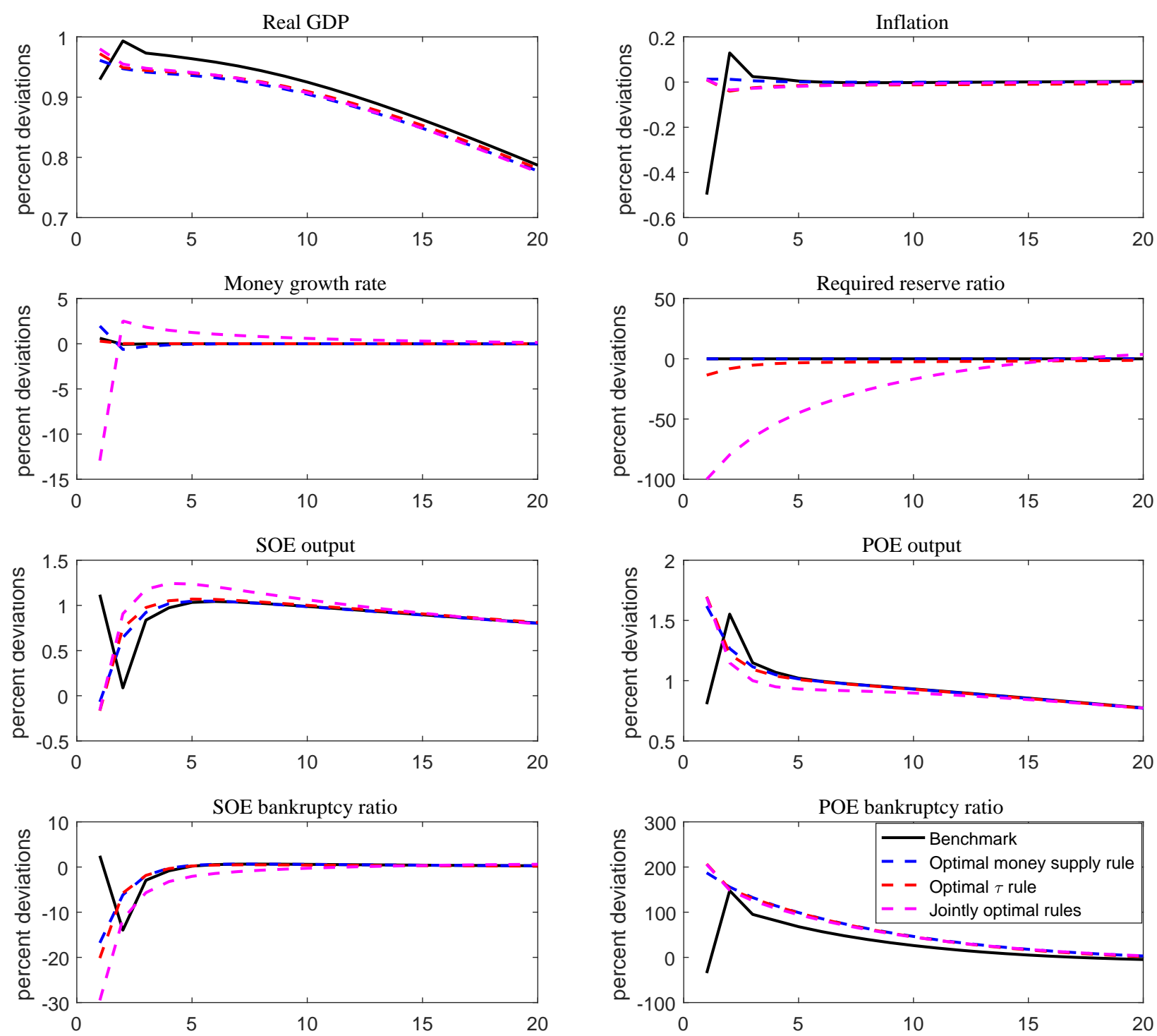

FIGURE 3. Impulse responses to a positive TFP shock under alternative policy rules. Benchmark rule: black solid lines; optimal money growth rule: blue dashed lines; optimal reserve requirement rule: red dashed lines; jointly optimal rule: magenta dashed lines. The horizontal axes show the quarters after the impact period of the shock. The units on the vertical axes are percent deviations from the steady state levels. 
Impulse responses to POE TFP shock
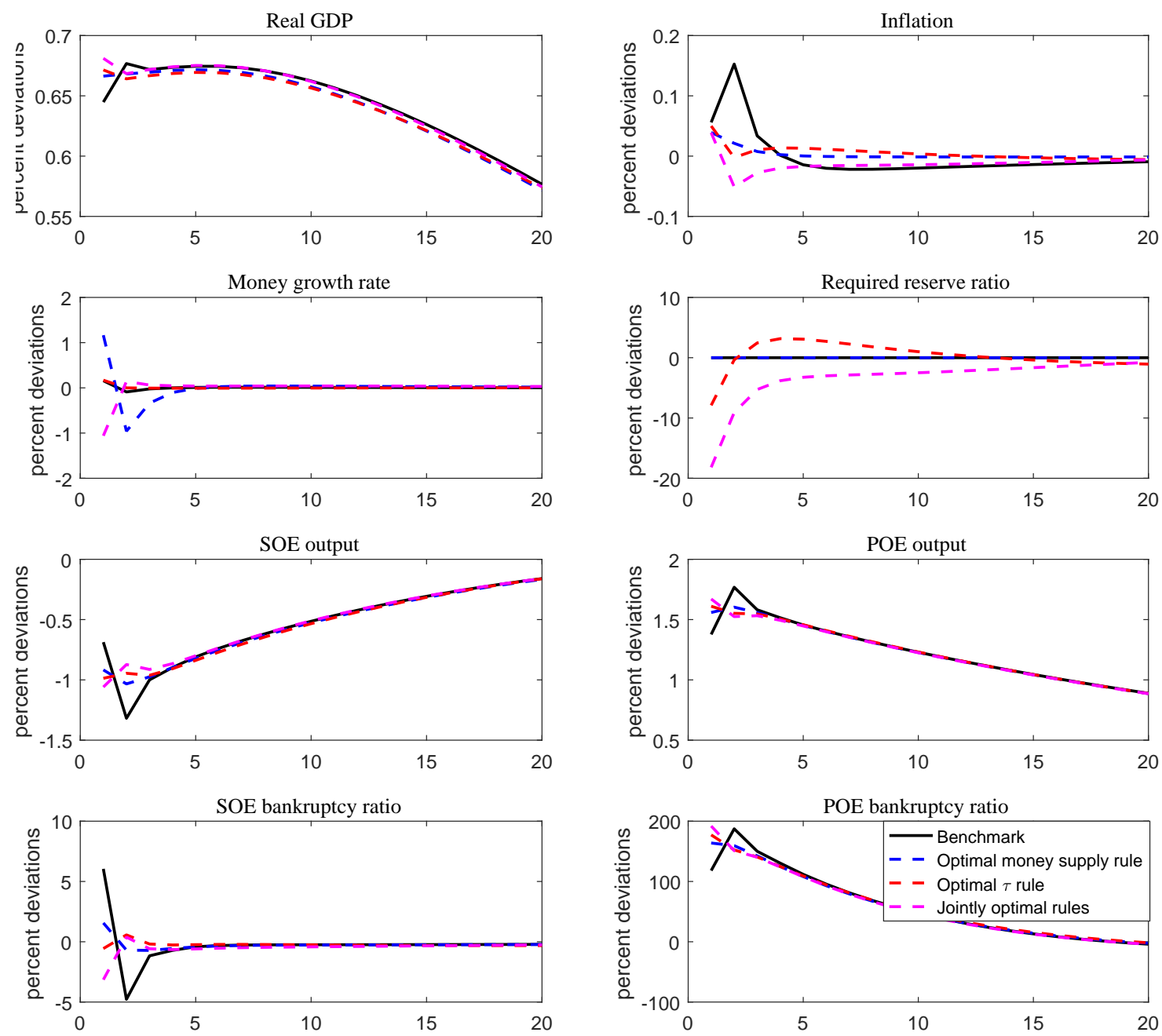

FIgURE 4. Impulse responses to a positive POE TFP shock under alternative policy rules. See the caption under Figure 3 for an explanation of lines and the units of the axes. 